This is an electronic reprint of the original article. This reprint may differ from the original in pagination and typographic detail.

Author(s): Kosonen, Heidi

Title: $\quad$ Ruoasta kaukaa mutta läheltä : symbolinen ruoka antropologisen tutkimuksen kohteena

Year: $\quad 2016$

Version:

Please cite the original version:

Kosonen, H. (2016). Ruoasta kaukaa mutta läheltä : symbolinen ruoka antropologisen tutkimuksen kohteena. Elore, 23(2). https://doi.org/10.30666/elore.79269

All material supplied via JYX is protected by copyright and other intellectual property rights, and duplication or sale of all or part of any of the repository collections is not permitted, except that material may be duplicated by you for your research use or educational purposes in electronic or print form. You must obtain permission for any other use. Electronic or print copies may not be offered, whether for sale or otherwise to anyone who is not an authorised user. 


\section{Ruoasta kaukaa mutta läheltä: symbolinen ruoka antropologisen tutkimuksen kohteena}

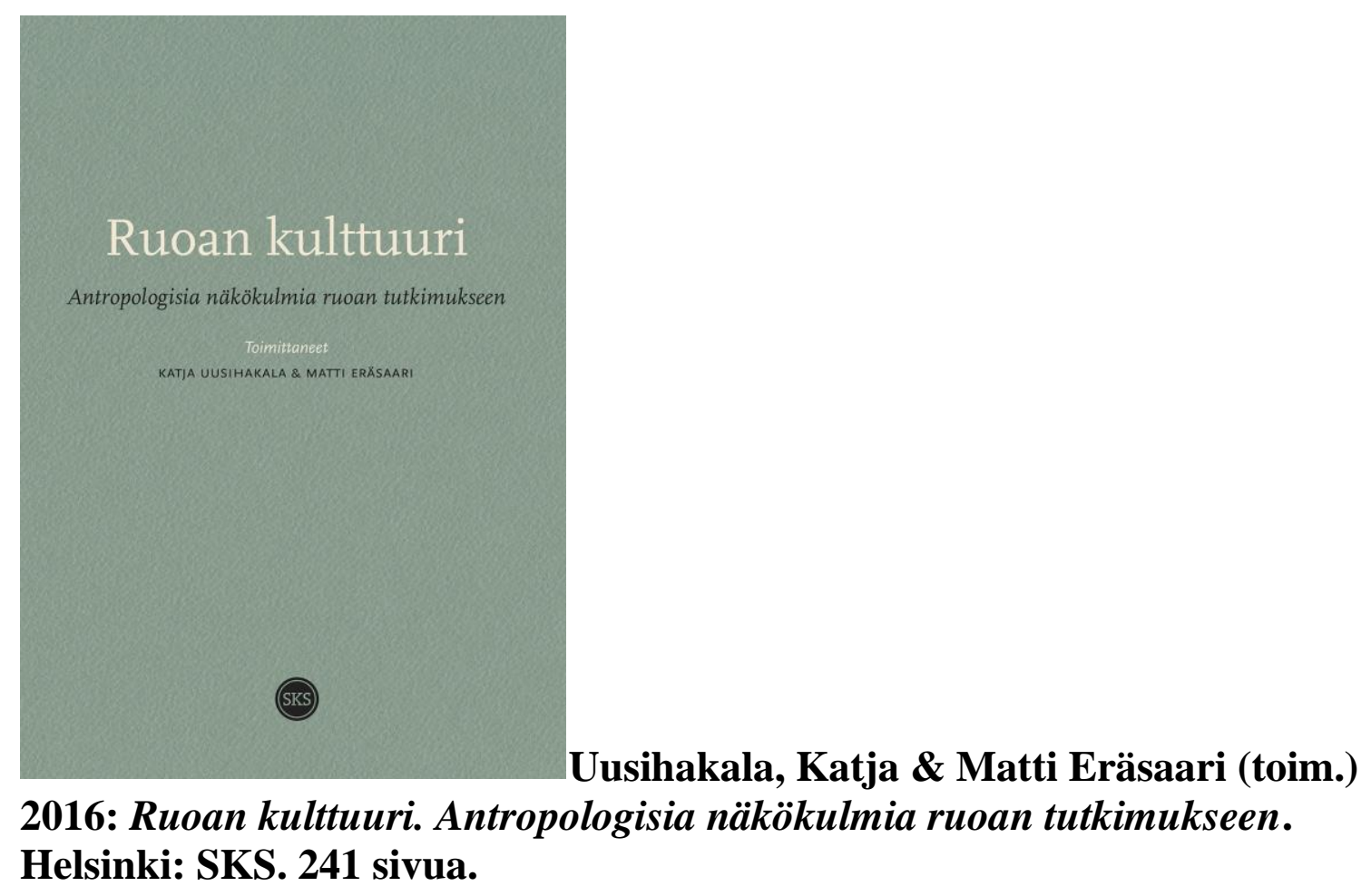

Heidi Kosonen

Ruoan kulttuuri. Antropologisia näkökulmia ruoan tutkimukseen on kotimainen, käytännönläheinen ja yleistajuinen perehdytys antropologiseen ruokatutkimukseen. Oivallisesti rajatussa artikkelikokoelmassa ruokaa tarkastellaan symbolisena järjestelmänä, jonka välityksellä ilmennetään erinäisiä sosiokulttuurisia rakenteita, kategorioita ja arvoja. Teoksessa käsitellään erityisesti ruoan roolia yhteisön, sukulaisuuden, sukupuolen ja kansallisidentiteetin rakentamisessa, rajaamisessa ja näkyviin tuottamisessa. Kirjan yhdeksän artikkelia perustuvat Tansaniassa, Kuubassa, Papua-Uudessa-Guineassa, Argentiinassa, Meksikossa, Indonesiassa, Etelä-Afrikassa, Kiribatilla ja Fidžillä tehtyyn etnografiseen kenttätutkimukseen.

\section{Sosiaaliset arvot ja symbolinen ruoka}

Ruokasymboliikan lähteillä liikutaan erityisesti Matti Eräsaaren, Johanna Pohjolan ja Toomas Grossin artikkeleissa. Pohjolan ja Grossin artikkeleita yhdistävät sekä antropologinen juomatutkimus että Shelly Ortnerin avainsymbolin käsite. Käsite viittaa sellaisiin rakenteellisesti olennaisiin symboleihin, jotka toimivat joko kokoavina tai jäsentävinä symboleina. Siinä missä edelliset tiivistävät yhteisiä arvoja, 
jälkimmäiset jäsentävät maailmaa analyyttisinä työkaluina. Ne siis erottelevat ihmisiä ja yhteisöjä siinä missä yhdistävätkin.

Johanna Pohjolan tarkastelema mate-juoma on tullut länsimaissa tutuksi seremoniallisesti jaettuna kuriositeettina, mutta alkuperäiskontekstissaan maten voisi miltei määritellä pyhäksi juomaksi. Artikkelissaan "Tässä maassa kukaan ei juo matea janoon'. Mate-juoma avainsymbolina Argentiinassa" Pohjola tarkastelee matea sellaisena hallitsevana symbolina, joka edustaa ihanteellista Argentiinaa sisäänpäin. Matepuhe välittää arvoja, jotka diskurssin tasolla rakentavat sosiaalisuutta ja ihanteellista kansallisuutta. Maten rituaalisessa jakamisessa tiivistyviä solidaarisia arvoja suojelevat moraaliset velvoitteet ja tabut, ja etenkin diskurssin tasolla maten jakamisen velvoite on ehdoton. Kuten Pohjola kuitenkin huomauttaa, mateen liittyvät sosiaalisia ihanteita huokuvat diskurssit ovat usein ristiriidassa käytännön kanssa. Tällöin diskurssissa esitetty sosiaalinen utopia saa väistyä milloin hygieniaan, milloin ideologiaan pohjautuvista syistä.

Myös Toomas Gross tarkastelee juoman sosiosymbolista roolia artikkelissaan "Mezcal ja meksikolaisuus. Juomisen symboliset ja sosiaaliset merkitykset Oaxassa”. Mezcalista tekevät erityisen kiintoisan tapausesimerkin ne viimeaikaiset kansainvälistämisyritykset, joissa työväenluokkaisesta alkoholijuomasta on pyritty rakentamaan eksoottista vetovoimatekijää. Symbolista vetovoimaa on omaksuttu Grossin erityisesti tarkastelemasta alueellisesta diskurssista, jossa parannusvoimaisena ja paikallisten "perimmäistä olemusta" kuvastavana esitetty mezcal on yltänyt kokoavan symbolin asemaan. Kuten mate, myös mezcal sitoo paikallisia yhteen myös nauttimisensa yhteydessä: se sekä toimii "sosiaalisena liimana" että rakentaa eroa muun muassa sukupuolten ja uskontokuntien välille. Oaxan protestanttisten käännynnäisten parissa mezcal saavuttaa Grossin mukaan jopa negatiivisen symbolin aseman viestiessään katolilaisten uskonnollisesta vääräoppisuudesta.

Matti Eräsaari puolestaan liikkuu aivan symbolisen järjestelmän kivijalalla artikkelissaan “Tosiruoka ja rahan syöminen. 'Raskaus' ja ruoan arvo Fidžillä”. Artikkelissa tarkasteltu eronteko "raskaaseen" ja "kevyeen" ruokaan perustuu ruoan fyysisten ominaisuuksien sijaan moraaliseen arvohierarkiaan ja ilmentää velvoitteiden ja vastavelvoitteiden varaan rakennettua perinteistä sosiaalista järjestelmää. Eräsaaren analysoimissa kyläläisdiskursseissa hyvästä, terveestä ruoasta viestivä "raskaus" kytkeytyy etenkin nostalgiseen menneeseen ja kyläläisten itseymmärrykseen ja muotoutuu suhteessa "rahaa syövään" kaupunkielämään. Kylissä itse kasvatettu, ravintoarvoiltaan kenties vähäisempi ruoka on hyvää, "raskasta", sillä se palautuu palvelemaan koko kyläyhteisön etua sosiaalisen vaihdon kautta. Rahalla kaupasta ostettava ruoka puolestaan nähdään epäravitsevana, koska se edustaa urbaania luksusta, joka on poissa kylälle ominaisesta sosiaalisesta vaihdosta. Diskurssissa tämä menneen ja nykyisen, kylän ja kaupungin välisiin kategorisiin erontekoihin perustuva erottelu raskaan ja kevyen ruoan välillä toimii siten välineenä jaettujen arvojen toisintamiselle.

\section{Ruoka ja ruumiillistunut huolenpito}

Ruoan merkitys hoivan ja huolenpidon välineenä nousee esille Heidi Härkösen ja Tuomas Tammiston analyyseissa. Härkösen artikkelissa "Ruoka, huolenpito ja rakkaus Havannassa, Kuubassa. Ruumis sosiaalisten suhteiden ilmentäjänä” ruoan kytkös hoivaan ilmentyy niin ruoan sosiaalisessa kierrossa kuin ruumiissa ja ruumista koskevissa diskursseissa. Ruoka sekä tuottaa että ylläpitää kuubalaista sosiaalista rakennetta ihmissuhteista valtion säännöstelyjärjestelmään. Kummallakin tasolla sukupuolirakenteet ovat näkyvästi läsnä: ne sekä kiteytyvät valtion äiti-lapsi-politiikassa että tulevat toistetuiksi ruoan kierrossa, jossa 
kuubalaismiesten odotetaan toimittavan naisille ja lapsille ruokalahjoja ja naisten edelleen valmistavan miehille ja lapsille ruokaa. Ruumiissa manifestoituva hoiva tuottaa näkyviin tätä sosiaalista järjestelmää ylläpitävää huolenpidon kierrettä. Diskurssien tasolla puolestaan tarkastellaan ruoan kierron myötä rakentuvien ihmissuhteiden laatua ja valtion kykyä huolehtia kansalaisistaan. Laadun indikaattoreina tärkeitä ovat sekä sukupuolieroa heijasteleva ero raa'an ja kypsän ruoan välillä että muun muassa ulkoperäisyyden varaan pingotettu ruoan arvohierarkia.

Tuomas Tammiston tarkastelussa ruoan välityksellä sosiaalista järjestystä rakentava hoiva kytkeytyy puolestaan kovaan työhön ja näyttäytyy sekä papua-uusi-guinealaisten mengenien käsityksessä sukulaisuudesta että näiden ruokahierarkiassa. Artikkelissaan "Sukulaisuus on kovaa työtä. Ruoka, huolenpito ja sukulaisuus mengenien keskuudessa” Tammisto dekonstruoi kentällä todistamaansa ruoan rituaaliseen jakamiseen liittyvää kiistaa erittelemällä mengeniläisten ruokakäytänteiden ja -symboleiden syntyä sekä ruoan roolia sosiaalisten suhteiden rakentamisessa. Yhteiskunnassa, jossa kaikki ovat sukua keskenään, ruoan viljely ja sen seremoniallinen vaihto eivät pelkästään yhdistä vaan myös erottavat, toisin sanoen vahvistavat olennaisia sukulaissuhteita epäolennaisten kustannuksella. Sukulaisuutta rakennetaan sillä kovalla työllä, jota kaskipuutarhojen jaetut palstat, ruokkimisessa näyttäytyvä huolenpito ja ruoan seremoniallinen jakaminen ilmentävät. Kypsentämättömän, uudelleen jaettavissa tai istutettavissa olevan ruoan jakaminen sallii kaskiviljelijäyhteisössä useampia ja kestävämpiä tapoja rakentaa ja ylläpitää sosiaalisuutta ja vaihtosuhteita kuin kypsennetyn ruoan jakaminen. Ruoan sosiaalinen arvo selittää Tammiston todistamaa kiistaa tilanteessa, jossa monikäyttöisemmän kypsentämättömän ruoan jakaminen edellyttäisi seremoniallisesta kaavasta poikkeamista.

\section{Ruoasta kieltäytymisen positiivisista merkityksistä}

Jos valtaosa Ruoan kulttuurin artikkeleista keskittyy sosiaalisuutta tuottaviin ja ylläpitäviin positiivisiin rakenteisiin - erilaisiin vaihtoihin ja vaihtosuhteisiin, jaettuihin ruokatilanteisiin ja seremonioihin - muutamassa kokoelman artikkelissa luodataan myös ruoasta tai yhdessä ruokailusta kieltäytymisen kaltaisia negatiivisia rakenteita ruokasosiaalisuuden osatekijöinä. Anu Lounelan ja Petra Aution artikkeleissa ruoasta kieltäytymisen etiketti paljastaa jotain kulttuurin ihanteista: itsehillinnästä tai autonomiasta.

Artikkelissaan "Ruoka sosiaalisen aseman merkitsijänä Jaavan vuoristoalueella. Mielihalut, hierarkia ja kommensaalisuuden välttely" Louhela tarkastelee keskijaavalaiseen etikettiin olennaisesti kuuluvaa yksin ruokailua. Länsimaisessa kontekstissa, jossa yhdessä ruokailu limittyy perheyksikköön ja positiivisiin arvoihin, kommensaalisuuden väheneminen on tavattu nähdä merkkinä keskeisten sosiaalisten rakenteiden rappeutumisesta. Lounelan tarkastelemalla Jaavalla ruokailu on kuitenkin ihanteellisessa muodossaan yksityinen tapahtuma. Kuten Lounela osoittaa, ruoka asettautuu yksityisen ja julkisen rajapinnalle siihen liittyvän stigmatisoidun halun kautta. Tällöin yksin syöminen ei ole pelkästään sosiaalinen normi vaan myös yksilön tapa välttää häpeää ja osoittaa itsehillintää. Matala halu on kuitenkin sidoksissa symboliseen järjestelmään, jossa tietyt ruoka-aineet tyhjentyvät ruokahaluun liittyvästä stigmasta. Esimerkiksi Lounelan esittelemä kassava korottaa syöjänsä statusta maskuliinisten kytköstensä kautta.

Myös Petra Aution artikkelissa "Ruoasta kieltäytyminen positiivisena tekona. Sosiaalisuus ja autonomian rakentaminen Etelä-Kiribatissa, Tyynellämerellä” kieltäytyminen kytkeytyy pohjimmiltaan kunniaan, tässä tapauksessa Tyynenmeren kontekstissa merkitysvoimaisen 
Marcel Maussin lahjateorian välityksellä. Autio dekonstruoi tapakulttuuria, jonka ristiriitaiset konventiot tuntuvat määräytyvän suhteessa sukulaisuuteen ja statukseen. Kuten Autio osoittaa, merkityksellisinä tekijöinä ruoan hyväksymisen ja siitä kieltäytymisen velvoitteissa näyttäytyvät yhtäältä eronteko sukulaisen ja ei-sukulaisen välillä ja toisaalta vieraan asema. Jälkimmäisessä tapauksessa ruoka on keino osoittaa vieraanvaraisuutta ja edellisessä se ilmentää oleellisia sukulaissuhteita. Samalla kieltäytyminen rakentaa käsitystä perhekuntien omavaraisuudesta ja riippumattomuudesta kulttuurissa, jossa maattomuus koetaan häpeälliseksi. Jos ruoka toimii välineenä sosiaalisuuden rakentamiselle, sen välityksellä myös käydään statuskilpailua.

\section{Muutos ja välineellinen ruoka}

Muutamassa kokoelman artikkelissa ruoka näyttäytyy keinona jäsentää ja hallita erityisesti muuttuvaa maailmaa. Tuulikki Pietilä käsittelee ruokaa diskursiivisena keinona kontrolloida uhkaa, jonka kulttuurinen murros ja sen seurauksena elättäjän asemaan nousseet torikauppiasnaiset asettavat perinteiselle kilimanjarolaiselle sukupuolijärjestykselle. Pietilän artikkeli "Syödä, juoda ja ruokkia. Sukulaisuus- ja muut suhteet Kilimanjarolla” rakentuu hedelmällisen ristiriidan varaan: haastateltujen kilimanjarolaisten torikauppiasnaisten tapa selittää kaupankäyntinsä taustavaikutteita sukupuolijärjestelmää myötäilevällä "ruokkimisella" tuntuu sekä kyseenalaistuvan kaupankäynnin taloudellisessa merkityksessä että tyhjentyvän diskurssissa, jossa maskuliinisuuteen kytkeytyvät olut ja liha toimivat kiinnekohtina torikauppiasnaisten moraalin kyseenalaistamisessa. Erittelemällä ruoan ja juoman symbolisia kytköksiä sukupuoleen, seksuaalimoraaliin ja sosiaaliseen järjestelmään Pietilä määritteleekin sekä torikauppiasnaisten itsensä hyödyntämän ruokintapuheen että torikauppiasnaisia arvostelevan keskustelun pyrkivän käsitteellistämään ja hallitsemaan käynnissä olevaa kulttuurista murrosta, joka uhkaa perinteistä sosiaalista rakennetta.

Katja Uusihakalan artikkelissa "Bring and Braai. Vieraanvaraisuuden muuttuvat käytännöt 'rhodesialaisessa' diasporayhteisössä Etelä-Afrikassa" ruoka puolestaan toimii nostalgisena kiinnekohtana diasporayhteisön identiteettiä rakentavalle muistelulle. Kuten Uusihakala kuvaa, bring and braai on muisteluperformanssi, jossa kansallisidentiteettiä toistetaan hieman muista rhodesialaisdiasporista poikkeavalla tavalla. Etelä-Afrikassa "aito afrikkalainen" ruoka on arkipäiväistä, joten muistelu painottuu ruokanostalgian sijaan ruokatapahtumaan itseensä. Kuten Pohjolan tarkastelemassa materingissä, diskurssissa esitetty ihanne ei bring and braai -käytännössäkään toteudu: kommensaalisena mutta omavaraisena grillitapahtumana bring and braai jää puutteelliseksi rhodesialaisidentiteetille keskeisen vieraanvaraisuuden osalta. Toisaalta omavaraisuus säästää ihmiset häpeältä. Diasporan aikaansaamassa anomiassa ruoan vastavuoroisen jakamisen edellytys saattaisi merkitä monet velalla, jota ei voida maksaa pois. Loppujen lopuksi bring and braai mahdollistaakin vieraanvaraisuuden ideaalin ylläpitämisen juuri diskurssin ilmentämässä rakenteellisessa nostalgiassa, jossa puutteellista bring and braai'ta peilataan suhteessa menneeseen.

\section{Monipuolinen ja eheä kokoelma}

Kuten Uusihakala ja Eräsaari johdannossa huomauttavat, ruoka ei koskaan ole "vain ravintoa" vaan merkityksellistä inhimillistä toimintaa; valikoiva symbolinen prosessi, joka heijastaa ja muovaa yhteisöjen ja ihmisten sosiokulttuurista elämää. Ruoan kulttuuri onkin hyvin tämän premissin ympärille rajattu kokoelma, jonka artikkelit keskustelevat keskenään toimivasti ja monipuolisesti. Artikkelit jättävät kritiikille hyvin vähän sijaa: kukin 
kirjoittajista johdattaa lukijaa relevanttien teorioiden ääreen oivaltavasti sekä kärsivällisesti kontekstualisoiden. Ruoan sosiaalisia merkityksiä esitellään tasapuolisesti sekä teorian että tutkimuskohteiden kautta.

Vaikka tutkimusartikkeleissa tarkastellut "ruokakulttuurit" ovat suomalaiselle lukijalleen väistämättä eksoottisia, kokoelma onnistuu sitomaan ne oivallisesti siihen ajankohtaiseen kontekstiin, jossa kirja on julkaistu. Havainnollistavaa vertailua suoritetaan sekä kokoelman johdannossa että monessa sen artikkelissa ja siten kommentoidaan muun muassa länsimaista ruumiinkuvaa, tuotantoketjuiltaan piilotettua kulutuskulttuuria ja Ravintolapäivän kaltaisten "uuskommensaalisten" tapahtumien nauttimaa suosiota. Ristiinvalotus ja vertaileva lähtökohta sallivat tarkastelussa olevien sisältöjen lähestymisen monista eri konteksteista ja tulokulmista. Sivistävä, havainnollistava ja mielenkiintoinen Ruoan kulttuuri vaikuttaisi olevan kaikilta osin onnistunut kokonaisuus.

FM Heidi Kosonen toimii tohtorikoulutettavana Jyväskylän yliopiston taiteiden ja kulttuurin tutkimuksen laitoksella. Hän viimeistelee väitöskirjaa seksuaalisuuteen ja kuolemaan kohdistuvan ruumiinkontrollin ilmenemisestä kuvakulttuurissa. 